\title{
The Effect of Hypnotherapy on Postpartum Pain and Depression in Women with Post Caesarean Delivery
}

\author{
Araafi Hariza Mahandaru'), Supriyadi Hari Respati'), \\ Sri Sulistyowati²), Abdurahman Laqif ${ }^{1}$, Hanung Prasetya ${ }^{3 \text { ) }}$ \\ 1)Department of Obstetrics and Gynecology, Faculty of Medicine, \\ Universitas Sebelas Maret/ Dr. Moewardi Hospital, Surakarta, Indonesia \\ 2)Department of Obstetrics and Gynecology, Faculty of Medicine, \\ Universitas Sebelas Maret/ Universitas Sebelas Maret Hospital \\ ${ }^{3)}$ Health Polytechnics, Ministry of Health, Surakarta
}

Background: Postoperative pain is one of the most common problems in women after cesarean section. Caesarean section is also associated with post-partum depression. Hypnotherapy is one of the complementary therapy options that are effective and efficient in reducing pain symptoms and post-partum depression. This study aimed to analyze the effect of hypnotherapy on the level of pain and post-partum depression in post-cesarean section patients.

Subjects and Method: This was an experimental single-blind randomized controlled trial with a post-test group design, which was conducted from January to April 2021, at the Dr. Moewardi and Universitas Sebelas Maret Hospitals, Surakarta. A sample of 80 patients with cesarean section was divided into two groups, namely 40 patients in the hypnotherapy group and 40 patients in the control group. The independent variable was hypnotherapy. The dependent variables were pain and depression. Hypnotherapy was carried out by self-hypnosis using audio recordings of hypnotherapy in 2 sessions before and after the cesarean section procedure. The pain was measured by the Numeric Rating Scale. Post- partum depression was measured by the Edinburgh Postnatal Depression Scale. The data were analyzed by an independent t-test.

Results: Post-cesarean section pain in the group of hypnotherapy (Mean $=4.58 ; \mathrm{SD}=$ 1.20) was lower than without hypnotherapy (Mean $=6.48 ; \mathrm{SD}=1.01)$, and it was statistically significant $(\mathrm{p}<0.001)$. Postpartum depression in the group of hypnotherapy (Mean=6.08; $\mathrm{SD}=1.60$ ) was lower than nonhypnotherapy group (Mean $=8.48 ; \mathrm{SD}=$ 3.78 ), and it was statistically significant (p $<0.001)$.

Conclusion: Hypnotherapy has a significant effect on reducing pain and post-partum depression in post-cesarean section patients.

Keywords: Hypnotherapy, pain levels, postpartum depression, post-cesarean section

\section{Correspondence:}

Araafi Hariza Mahandaru. Department of Obstetrics and Gynecology, Faculty of Medicine, Universitas Sebelas Maret/ Dr. Moewardi Hospital, Surakarta, Jl. Kolonel Sutarto, Jebres, Surakarta 57126, Central Java. Email: mahandarurafi@gmail.com.

\section{Cite this as:}

Mahandaru AH, Respati SH, Sulistyowati S, Laqif A, Prasetya H (2021). The Effect of Hypnotherapy on Postpartum Pain and Depression Levels in Women with Post Caesarean Delivery. Indones J Med. 06(02): 194-205. https://doi.org/10.26911/theijmed.2021.06.02.08.

cC) (i) (2) Indonesian Journal of Medicine is licensed under a Creative Commons

EY NC SA Attribution-NonCommercial-ShareAlike 4.0 International License.

\section{BACKGROUND}

Deliveries by cesarean section accounted for $18.6 \%$ of all births and experienced a global increase of $12.4 \%$ (Betrán et al.,
2016). According to the 2011 national survey, the number of cesarean sections in Indonesia was $24.8 \%$ (Wahyuni and Rohani, 2019). Although seen as a measure 
that can prevent maternal and fetal mortality, cesarean section is associated with short-term and long-term health risks to the mother (Sandall et al., 2018).

Postoperative pain is one of the most frequently reported problems in women after cesarean section (ACOG, 2013). The pain of moderate to severe intensity occurred in $77.4 \%$ to $100 \%$ of women after cesarean section in the first 48 hours postoperatively (Borges et al., 2017; Jasim et al., 2017). Postoperative pain occurs due to activation of exposed free nerve endings during tissue discontinuity and a series of central sensitization and modulation processes involving various inflammatory mediators (IASP, 2018). Pain can hinder a mother's ability to care for herself and her baby. Pain that is not handled properly can be a greater risk of opioid use, the onset of post-partum depression, and chronic pain (ACOG, 2013).

Post-partum depression is one of the maternal psychological effects of cesarean section (Carter et al., 2006; Mubarokah et al., 2020). Post-partum depression occurs in $13 \%$ of women after cesarean section globally, $17 \%$ in Asia, and $20.7 \%$ in Indonesia (Iwata et al., 2015; Dira et al., 2016; Thompson et al., 2019). A meta-analysis study of $\mathrm{Xu}$ et al. (2017), the risk of postpartum depression increased 1.15 times $(\mathrm{OR}=1.15 ; 95 \% \mathrm{CI}=0.92$ to $1.43 ; \mathrm{p}=0.178)$ in elective cesarean section women and 1.47 times $(\mathrm{OR}=1.47 ; 95 \% \mathrm{CI}=1.33$ to $1.62 ; \mathrm{p}=$ o.069) in emergency cesarean section (Xu et al., 2017). This is caused by several factors such as decreased oxytocin levels in women after cesarean section, hormonal factors, inflammatory factors, psychological factors, socioeconomic factors, and environmental factors (Payne et al., 2019). Depression can cause anxiety, feelings of inefficiency in caring for babies, inability to adapt to new situations, loss of control, obsessive thoughts, irrational fear to feelings of disappointment (Mughal et al., 2020). Post-partum depression can also disrupt parenting and child development (Carter et al., 2006).

Hypnotherapy is one of the complementary therapy options that are effective and efficient in reducing pain symptoms and post-partum depression. Hypnotherapy is a state of responsive awareness modification that involves a partial focus of attention to reduce awareness of external environmental influences (Azizmohammadi et al., 2019). The effect of hypnotherapy on pain is explained through the induction of positive emotions that are generated during the hypnosis process, which can increase norepinephrine performance which in turn has an impact on decreasing inflammatory mediators such as interleukin-1, interleukin-6, prostaglandins, and TNF $\alpha$. Changes in sensory impulses and activity of the autonomic nervous system occur in the hypnosis process (Sanders, 2012). The effect of hypnotherapy on depressive symptoms can be explained by an increase in serotonin receptors (5-Hydroxy Tryptamine) in the brain, an increase in oxytocin secretion from the paraventricular nucleus posterior pituitary, and a decrease in cortisol levels (Varga et al., 2014; Kaufman et al., 2016). The hypnotic process also decreases the stimulation/ activation of TRP-metabolising enzyme indolamine-2,3dioxygenase (IDO), which inhibits the production of 3-hydroxy- kynurenine $(3 \mathrm{OH}-\mathrm{KYN})$ and quinolinic acid (QUIN) from tryptophan so that the availability of tryptophan in the brain increases, followed by an increase in serotonin synthesis (Sanders, 2012).

Hypnotherapy can be easily administered, has few or no side effects, and inexpensive. It is delivered in an audio recording or self-hypnosis format that does 
not require the presence of a practitioner (Thompson et al., 2019). Hypnotherapy can be a single or repeated session with more than 1 hypnotherapy session with a duration of less than 30 minutes, which will be more effective in reducing pain (Kendrick et al., 2016). Hypnosis can be given as prevention against post-partum depression where the intervention is carried out in several sessions at gestational age 16, 20, 28, and 36 weeks antepartum, or it can also be given as post-partum depression therapy where the intervention is given postpartum (Yexley, 2007; Beevi et al., 2019).

The selection of a safe and effective method of managing post-partum pain and depression is very important to prevent the adverse effects of cesarean section. Through this research, the researcher aimed to know the effect of hypnotherapy on the incidence of post-partum depression and pain in pregnant women who had cesarean section, where hypnotherapy could be an efficient and effective alternative complementary therapy.

\section{SUBJECTS AND METHOD}

\section{Study Design}

This was an experimental single-blind randomized controlled trial group post-test design conducted from January to March 2021. The study was conducted in the Obstetrics and Gynecology Room at Dr. Moewardi and Universitas Sebelas Maret Hospitals, Surakarta.

\section{Population and Sample}

The subjects of the study were pregnant patients with indications for the section of the area who met the inclusion criteria in the form of emergency and elective cesarean section patients with spinal bupivacaine who were willing to participate in the study as respondents; getting ketorolac as a postoperative analgesic; able to communicate well using Indonesian language, hearing within normal limits, able to read and write, able to attend hypnotherapy sessions and at least graduate from elementary school who is treated in the Obstetrics and Gynecology Room at Dr. Moewardi and Universitas Sebelas Maret Hospitals.

Patients admitted to the intensive care unit; have a previous history of mental disorders and have complications such as heart disease, preeclampsia with complications, chronic renal failure, and other comorbidities that interfere with the body's metabolism, including the exclusion group. The sample size in this study was determined using the rule of thumb formula, and a minimum sample size of 40 patients was determined for each control and treatment group.

\section{Study Variable}

The dependent variables were pain and post-partum depression. The independent variable was hypnotherapy.

\section{Operational Definition of Variables} a. Hypnotherapy

Hypnotherapy is a process of giving suggestions through hypnosis to reduce a person's logical and analytical functions so that they can enter messages that will be recorded in the subconscious. In this study, hypnotherapy was carried out by selfhypnosis using standardized hypnotherapy audio recording media, which was given as many as 2 sessions before and after the cesarean section procedure in the treatment group with the nominal data scale type.

\section{b. Pain Level}

Pain is a subjective sensory experience caused by tissue damage. In this study, the pain level was measured using the Numeric Rating Scale (NRS) after the cesarean section on a scale of 1 - 10 with a numerical data scale.

\section{c. Depression Level}

Post-partum depression is an onset of major depression from the peripartum to 
the first 4 weeks post-partum. In this study, the level of depression was measured using the Edinburg Postnatal Depression Scale (EPDS) questionnaire at 7 days after the cesarean section on a scale of $0-30$, where the cut-off $\geq 13$ is post-partum depression with a numerical data scale.

\section{Research Technique}

After simple randomization was carried out in the 2 groups, hypnotherapy was carried out in the treatment group for 2 sessions. Session I was carried out before the cesarean section, and session II was performed 6-12 hours after the cesarean section while the patient was still under the influence of standard ketorolac analgesic therapy. Hypnotherapy is carried out using the selfhypnosis method with standard hypnotherapy audio recording media for 30 minutes in stages; pre-induction (introduction, explaining goals, and building trust), filling in the informed consent sheet, explaining the use of tools, induction (the relaxation process brings the patient to the subconscious mind with Hanung techniques), deepening (trance), suggestion (giving messages with the aim of certain), and termination (slowly awakening the patient). The control group still received the same standard analgesic therapy without being given hypnotherapy.

Both the treatment and control groups were accompanied to fill out the Numeric Rating Scale (NRS) questionnaire at 24 hours after cesarean section and the Edinburg Post Natal Depression Scale (EPDS) questionnaire at 7 days after cesarean section.

\section{Data Analysis}

The results of the data normality test were the Kolmogorov-Smirnov test. Hypothesis testing was done by using the independent t-test.

\section{Research Ethics}

This study had received ethical approval from the ethics committee of Dr. Moewardi Hospital Surakarta, dated No. 259 / III / HREC / 2021.

\section{RESULTS}

1. Characteristics of Study Subjects

Before further analysis was carried out, the characteristics of the research subject of each group were first explained, which included demographic variables such as education level (low-medium and high), income (above and below the UMR), occupation, method of financing, obese/ nonobese BMI, total parity consisting of primiparous and multiparous, gestational age (preterm and term), indications for cesarean section (emergency or elective), and delivery outcomes that can be seen from the infant's APGAR.

The majority of study subjects had low and middle education (83.75\%), income above the minimum wage (82.5\%), housewives (65\%), financing with insurance (85\%), non-obese body mass index (60\%), Multiparous women (73.75\%), term pregnancy (77.5\%), emergency cesarean section (81.25\%), primary cesarean section (90\%), and good delivery outcome (66.25\%) were assessed by the APGAR score.

\section{Bivariate Analysis}

Table 2 showed that the level of postcesarean section pain in the treatment group after receiving hypnotherapy (Mean= $4.58 ; \mathrm{SD}=1.20$ ) was lower than the nonhypnotherapy group (Mean= 6.48; $\mathrm{SD}=$ 1.01), and the difference was statistically significant $(\mathrm{p}<0.001)$. 
Mahandaru et al./ Hypnotherapy on Postpartum Pain and Depression

Table 1. Characteristics of study subjects for each group (categorical data)

\begin{tabular}{|c|c|c|c|c|}
\hline \multirow{2}{*}{ Characteristics } & \multicolumn{2}{|c|}{ Hypnotherapy } & \multicolumn{2}{|c|}{ Control } \\
\hline & $\mathbf{N}$ & (\%) & $\mathbf{N}$ & (\%) \\
\hline \multicolumn{5}{|l|}{ Educational background } \\
\hline - Primary-Middle & 34 & $(42.5)$ & 33 & $(41.25)$ \\
\hline - High & 6 & $(7.5)$ & 7 & $(8.75)$ \\
\hline \multicolumn{5}{|l|}{ Income } \\
\hline - Over the minimum wage & 36 & (45) & 30 & $(37.5)$ \\
\hline - Under theminimum wage & 4 & (5) & 10 & $(12.5)$ \\
\hline \multicolumn{5}{|l|}{ Occupation } \\
\hline - Working & 15 & (18.75) & 13 & (16.25) \\
\hline - Housewife & 25 & $(31.25)$ & 27 & $(33.75)$ \\
\hline \multicolumn{5}{|l|}{ Financing/Funding } \\
\hline - Insurance & 34 & $(42.5)$ & 34 & $(42.5)$ \\
\hline - Generic & 6 & $(7.5)$ & 6 & $(7.5)$ \\
\hline \multicolumn{5}{|l|}{ BMI } \\
\hline - Non obese & 22 & $(27.5)$ & 26 & $(32.5)$ \\
\hline - Obese & 18 & $(22.5)$ & 14 & $(17.5)$ \\
\hline \multicolumn{5}{|l|}{ Total Parity } \\
\hline - Primipara & 8 & (10) & 13 & $(16.25)$ \\
\hline - Multipara & 32 & $(40)$ & 27 & $(33.75)$ \\
\hline \multicolumn{5}{|l|}{ Gestational Age } \\
\hline - Preterm & 11 & $(13.75)$ & 7 & $(8.75)$ \\
\hline - Aterm & 29 & $(36.25)$ & 33 & $(41.25)$ \\
\hline \multicolumn{5}{|c|}{ Indication for Caesarean Section } \\
\hline - Elective & 10 & $(12.5)$ & 5 & $(6.25)$ \\
\hline - Emergency & 30 & $(37.5)$ & 35 & $(43 \cdot 75)$ \\
\hline \multicolumn{5}{|c|}{ History of the Caesarean Section } \\
\hline - Primary & 36 & $(42.5)$ & 36 & $(42.5)$ \\
\hline - History of the Sesarea Section & 4 & $(7 \cdot 5)$ & 4 & $(7.5)$ \\
\hline \multicolumn{5}{|l|}{ APGAR } \\
\hline - Good & 28 & (35) & 25 & $(31.25)$ \\
\hline - Poor & 12 & (15) & 15 & $(18.75)$ \\
\hline
\end{tabular}

Table 2. Differences in the mean level of post-partum pain after being given hypnotherapy

\begin{tabular}{lcccc}
\hline \multirow{2}{*}{ Group } & \multicolumn{3}{c}{ Pain Level } & p \\
\cline { 2 - 4 } & Mean & SD & $<0.001$ \\
\hline Intervention & 4.58 & 1.20 & \\
Control & 6.48 & 1.01 & \\
\hline
\end{tabular}

Table 3. Differences in mean levels of post-partum depression after being given hypnotherapy

\begin{tabular}{lccc}
\hline \multirow{2}{*}{ Group } & \multicolumn{2}{c}{ Depression Level } & \multirow{2}{*}{ p } \\
\cline { 2 - 4 } & Mean & SD & $<0.001$ \\
Intervention & 6.08 & 1.59 & \\
Control & 8.48 & 3.78 & \\
\hline
\end{tabular}

Table 3 showed that the level of postpartum depression after cesarean section in the treatment group after receiving hypno- therapy $(\mathrm{Mean}=6.08 ; \mathrm{SD}=1.60)$ was lower than the non-hypnotherapy group (Mean= 
8.48; $\mathrm{SD}=3.78)$, and the difference was statistically significant ( $\mathrm{p}<0.001$ ).

\section{DISCUSSION}

\section{The Effect of Hypnotherapy on Pain Levels}

Postoperative pain occurs due to stimulation of the free nerve endings (Free Nerve Ending) by a tissue trauma stimulus that triggers the release of some inflammatory mediators passed through the type $\mathrm{C}$ nerve fibres to the dorsal root ganglion. The stimulus will be modulated through various neurotransmitter mediators, both sensitizing and inhibitory at several levels in the spinothalamic pain pathway, before finally being conveyed to the somatosensory cortex (Han et al., 2015).

Post-cesarean section pain occurs in $77.4-100 \%$ of women with moderate to severe intensity in the first 48 hours (Borges et al., 2017; Jasim et al., 2017). Pain intensity after cesarean section is influenced by the duration of surgery, obesity, extensive dissection, and the possibility of anaesthesia at a lower level of the dermatome (Jasim et al., 2017). In this study, there were 20 patients with severe pain (25\%), 51 patients with moderate pain (63.75\%), and 9 patients with mild pain (11.25\%).

Pain is a subjective experience with differences in thresholds and perceptions for each individual, so an objective and easy-to-use pain measurement tool is needed to quantify pain (Tripathi et al., 2014). In this study, the level of pain in the subject was assessed using the Numeric Rating Scale instrument (NRS) because it has clearer limitations than the Visual Analog Scale (VAS), which has unlimited possibilities (Haefeli et al., 2006). NRS is easy to understand, especially in patients with visual impairments and has been tested valid (>0.90) and reliable (>0.95) (Jasim et al., 2017).

Hypnotherapy is believed to help reduce postoperative pain by giving suggestions in the form of positive command sentences (Kendrick et al., 2016). Through the hypnosis process, the patient is brought into a more relaxed condition so that the autonomic nervous system will be calmer and the induction of positive emotions that affect the patient's coping mechanism on pain perception (Sadock et al., 2015). The induction of positive emotions triggers more norepinephrine production, reduces ROS production, increases tryptophan levels, and stimulates the ventricular nucleus to secrete oxytocin which will act on the dopamine system, which plays a role in pain modulation (Sanders, 2012; Varga et al., 2014). Deeper hypnotic conditions (trance) can help activate the endorphins and enkephalin systems which can inhibit the production of substance $\mathrm{P}$, a pain sensitizing agent in the dorsal horn of the spinal cord (Price et al., 2012; Sadock et al., 2015).

In this study, the average NRS value in the group given hypnotherapy treatment was 4.58 and in the control group was 6.48. Independent t-test (Table 2) showed a significant difference between the mean numeric rating scale of the hypnotherapy treatment group compared to the control group ( $\mathrm{p}<0.001)$.

The results of this study were in line with Aini and Pratidina (2017), which was conducted on 30 post-cesarean subjects divided into two groups, where 15 subjects were given hypnotherapy treatment, and 15 subjects were a control group who were not given hypnotherapy. The results showed that there was a significant effect related to hypnotherapy on pain intensity as measured by numeric rate scale in postcesarean section patients at PKU Muham- 
madiyah Temanggung Hospital with pvalue $<0.050$ (Aini et al., 2017).

Niraski (2015) also showed the same results where hypnotherapy and standard hospital therapy can reduce pain intensity in post-cesarean section patients. In this study, the marginal homogeneity test showed a significant reduction in pain levels before and after the intervention. Twelve post-cesarean patients were given hypnotherapy with standard hospital analgesic therapy with $\mathrm{p}=0.001$ compared to 12 patients who received only standard hospital analgesic therapy. The results of the chi-square test in the two groups showed $\mathrm{p}=0.030$, which meant that there was a difference in the level of pain in the treatment group that was given a combination of analgesics and hypnotherapy compared to the control group which was only given analgesics (Niraski, 2015).

Beevi et al. (2017) discussed the effectiveness of hypnosis at delivery and 24 hours post-partum carried out on 23 subjects in the treatment group and 22 subjects in the control group. In this study, a hypnosis intervention was carried out in the treatment group at $16,20,28$, and 36 weeks of gestation. In contrast, the control group was only given antenatal care, but both used pethidine at delivery. The results showed significant differences related to the use of pethidine which in the treatment group was lower than the control group (Beevi et al., 2017).

A review conducted by Azizmuhammadi (2019) regarding the use of hypnosis in the management of pain during labor stated that many studies had shown a reduction in pain and a decrease in childbirth complications after hypnotherapy. Still, there have not been sufficient studies to prove the productivity of hypnotherapy.

This was in accordance with the function of hypnotherapy as a complementary therapy where its function is as a complement and does not negate standard treatment for pain (Kravits, 2013).

The results of this study were also different from the review study conducted by Madden et al. (2016). They discussed the effect of hypnosis in childbirth using the RCT method and the quasi method, which obtained a total of 2,954 research subjects. The results showed no significant difference in the value of pain between the hypnotherapy treatment group and the control group that only received analgesics, with a 95\% CI result reaching 0.57-0.94. In this study, apart from assessing the intensity of pain, the satisfaction of pain relief was also assessed, and the results did not show a significant difference for the two groups (Madden et al., 2016). This was probably due to the use of epidural analgesics, which is a strong type of fentanyl analgesic, which is a synthetic opioid class used for severe pain during labor. This was in line with studies which stated that hypnotherapy will be more effective, especially in types of pain with mild to moderate intensity (Beevi et al., 2017).

\section{The Effect of Hypnotherapy on Postpartum Depression}

Payne and Maguire's (2019) study described a complex relationship between cesarean section and post partum depression, such as a decrease in oxytocin levels which caused degradation of serotonin and dopamine, an inflammatory factor that triggers cortisol withdrawal from the hormones estrogen and progesterone which affected the hypothalamus pituitary adrenal axis ( HPA axis) and environmental factors (Payne et al., 2019).

The instrument for measuring postpartum depression in this study used the Edinburgh post-natal depression scale (EPDS), which is a measurement tool that is widely used in various countries for 
screening for post-partum depression and has been tested for its validity and reliability in Indonesia $(r=0.67)$, and has a sensitivity of $87.5 \%$ and specificity of $61.6 \%$ in screening for post-partum depression (Alifah, 2016). Of the 80 study subjects, 12 patients (15\%) who had an Edinburgh postnatal depression score scale $\geq 13$ points indicated the presence of post-partum depression, all of whom came from the control group.

Through the process of suggestion, induction of positive emotions in a relaxed hypnosis state during hypnotherapy will reduce negative experiences that can trigger stress and cortisol secretion (Varga et al., 2014). The secretion of oxytocin by the paraventricular nucleus of neurohypophysis increases, thereby decreasing dopamine degradation by Co-methyl Transferase (COMT) and increasing the production of tryptophan and serotonin (Han et al., 2015). Stimulation of the N-methyl diaspartate (NMDA) receptor, which can cause atrophy in the hippocampus, is also reduced by the induction of positive emotions so that it can reduce symptoms of depression (Sanders, 2012).

In this study, the mean value of the Edinburg postnatal depression scale in the group given hypnotherapy treatment was 6.08 and in the control group was 8.48. The independent t-test (Table 3) obtained $\mathrm{p}$ $<0.001$, which indicated that there was a significant difference between the mean values of Eidineburg postnatal depression scalp in the hypnotherapy treatment group compared to the group.

This study was in line with Beevi et al. (2019), who discussed the effectiveness of hypnosis against psychological disorders in post-partum using a quasi-experimental method consisting of 28 treatment group subjects who were given hypnotherapy at $16,20,28$, and 30 weeks of gestation. Ante- natal care then measured the symptoms of psychological disorders using the Depression, Anxiety, and Stress Scale-21 (DASS-21) questionnaire and the Edinburg postnatal depression scale for depression after 2 months post-partum. The results showed that there was a significant decrease in anxiety and depression in the treatment group compared to the control group with $\mathrm{p}=0.023$ and $\mathrm{p}=0.002$, respectively (Beevi et al., 2019).

This study found the same results as the case report reported by Yexley (2007), which stated the success of hypnotherapy therapy in post-partum depression patients who carried out 2 sessions, namely induction and 2 weeks later given positive suggestion intervention (Yexley, 2007).

The results of this study were also in line with Setyadi et al. (2016), who examined the effects of hypnotherapy on depression, anxiety, and stress. Still, this study used a patient population with HIV / AIDS. The frequency of hypnotherapy was given 4 times a month and measured using the Depression, Anxiety, and Stress Scale42 (DASS-42) questionnaire before and after hypnotherapy. The results showed that hypnotherapy can significantly reduce symptoms of depression, anxiety, and stress in people with HIV/ AIDS with a p-value $<0.001$ (Setyadi et al., 2016).

A review study conducted by Madden et al. (2016) which discussed hypnosis in childbirth, showed a study conducted by Downe by providing hypnotherapy treatment to 197 subjects and 179 subjects as a control group with the result that there was a significant decrease in the value of the Edinburg postnatal depression scale in the treatment group compared to the control group (95\% CI $=-0.28$ to $-0.15 ; \mathrm{p}<0.001$ ), but there were other studies that showed different results. From Werner's study, using 24 subjects as a group given hypno- 
therapy and 28 subjects as a control group, gave the result that there was no significant difference between the value of the Edinburg postnatal depression scale in the two groups after 6 weeks post-partum (95\% CI= 0.51 to $1.46 ; p=0.57$ ). It was explained in the limitations of the study that the nonsignificant results were likely due to the interpretation of the results, which are limited by methodological deficiencies including lack of randomization, hypnotic methods that were not clearly described, and the relatively small sample size (Madden et al., 2016).

A review study conducted by Sado et al. (2012), who collected several studies using the Randomized Controlled Trials (RCT) method without participating in the quasi-experimental method, stated no evidence that hypnosis could prevent the incidence of post-partum depression. This is probably due to the various types of hypnosis methods on various RCTs and different measuring instruments such as the Depression Anxiety Stress Scale, MMPI Depression Scale, and also the Edinburgh Postnatal Depression Scale. This review also stated that many studies using methods other than RCTs showed the effect of hypnosis on reducing symptoms of postpartum depression (Sado et al., 2012).

In this study, there are several limitations caused by a lack of time and energy. Hypnosis giving a session in this study was only conducted in 2 sessions. According to Kendrick et al. (2016), hypnotherapy will have a better effect on pain if repeated more than 1 session and $<30$ minutes per session. For example, as in the research of Beevi et al. (2019), hypnotherapy sessions were carried out 4 times at 16, 20, 28, and 36 weeks of gestation. Other limitations include not carrying out a suggestibility test that can predict the success of hypnosis, monitoring of the administration of addi- tional analgesics. At the same time, the patient was in poor care and lacked of follow-up time for symptoms of postpartum depression.

This study concluded that hypnotherapy had a significant effect on reducing the level of post-partum pain and depression in post-cesarean section patients. Thus, the implications of using hypnotherapy as a safe and easy therapy can be applied to the management of post-partum pain and depression. As suggestions for further study, the authors recommended giving more hypnotherapy sessions, different hypnotherapy methods, close monitoring of additional analgesic drugs, and a longer follow-up of post-partum depression symptoms.

\section{AUTHOR CONTRIBUTION}

Araafi Hariza Mahandaru, Supriyadi Hari Respati, Sri Sulistyowati, Abdurahman Laqif, Hanung Prasetya, did hypnotherapy, measured the pain and depression, collect the data, did data analysis, and wrote the paper.

\section{CONFLICT OF INTEREST}

The authors stated that the research was conducted in the absence of a commercial or financial relationship which could be construed as a potential conflict of interest.

\section{FUNDING AND SPONSORSHIP}

This study was self-funded.

\section{ACKNOWLEDGEMENT}

We would like to thank the Director of Dr. Moewardi Hospital Surakarta and Universitas Sebelas Maret Hospital for allowing this research to take place.

\section{REFERENCE}

ACOG (2013). ACOG committee opinion no. 559: Cesarean delivery on mater- 
Mahandaru et al./ Hypnotherapy on Postpartum Pain and Depression

nal request. Obstet Gynecol, 121(4): 904-907. https://doi.org/10.1097/o1.aog.0000428647.67925.d3.

Aini F, Pratidina ESG (2017). Pengaruh hipnoterapi terhadap intensitas nyeri pada pasien post section cesarea di Rumah Sakit PKU Muhammadiyah Kabupaten Temanggung (The effect of hypnotherapy on pain intensity in post section cesarean patients at PKU Muhammadiyah Hospital, Temanggung Regency). Pros Semin Nasdan Int, 1(1): 163-171.

Alifah FN (2016). Hubungan faktor psikososial terhadap kejadian post partum blues di ruang nifas RSUD dr. Abdoer Rahem Situbondo (The relationship between psychosocial factors and the incidence of post partum blues in the postpartum ward of Dr. Abdoer Rahem Situbondo Hospital). 1-104. http://repository.unair.ac.id/id/eprin t/54236.

Azizmohammadi S, Sima A (2019). Hypnotherapy in management of delivery pain: A review. Eur J Trans Myol, 29(3): 210-217. https://dx.doi.org/10.4081\%2Fejtm.2019.8365.

Beevi Z, Low WY, Hassan J (2017). The effectiveness of hypnosis intervention for labor: An experimental study. Am J Clin Hyp, 60(2): 172-191. https://dx.doi.org/10.1080/00029157.2017.1 280659.

Beevi Z, Low WY, Hassan J (2019). The effectiveness of hypnosis intervention in alleviating post-partum psychological symptoms. Am JClin Hyp, 61(4): 409-425. https://dx.doi.org/10.108o/oo029157.2018.1538870.

Betrán AP, Ye J, Moller AB, Zhang J, Gülmezoglu AM, Torloni MR (2016). The increasing trend in caesarean section rates: Global, regional and national estimates: 1990-2014. PLoS ONE,
11(2): 1-12. https://dx.doi.org/10.1371/journal.pone.0148343.

Borges N, Ce Silva BC, Pedroso CF, Silva TC, Tatagiba BSF, dan Pereira LV (2017). Postoperative pain in women undergoing caesarean section. Enferm Glob, 16(4): 374-383.

Carter FA, Frampton CMA, Mulder RT (2006). Cesarean section and postpartum depression: A review of the evidence examining the link. Psychosom Med, 68(2): 321-330. doi: 10.1097/o1.psy.00o0204787.83768.oc.

Dira IKPA, Wahyuni AAS (2016). Prevalensi dan faktor risiko depresi postpartum di kota Denpasar menggunakan Edinburgh postnatal depression scale (Prevalence and Risk factors for postpartum depression in Denpasar city using the Edinburgh postnatal depression scale). E-Jurnal Med Udayana, 5(7): 5-9. https://ojs.unud.ac.id/index.php/eum/article/view/21560.

Haefeli M, Elfering A (2006). Pain assessment. Eur Spine J, 15(1): 17-24. https://dx.doi.org/10.1007/soo586005-1044-x.

Han C, Pae CU (2015). Pain and depression: A neurobiological perspective of their relationship. Psychiatry Investig, 12(1);1-8. doi: 10.4306/pi.2015.12.1.1.

IASP (2018). IASP Announces revised definition of pain. IASP, 1 . Tersedia pada: https://www.iasp-pain.org/PublicationsNews/NewsDetail.aspx?ItemNum ber=9218\%oAhttps://journals.lww.co $\mathrm{m} /$ pain/Abstract/900o/The_revised _International_Association_for_the. 98346.aspx\%oAhttps://www.iasppain.org/PublicationsNews/NewsDet ail.aspx?ItemNumber $=10475$.

Iwata $\mathrm{H}$, Mori E, Tsuchiya M, Sakajo A, Maehara K, Ozawa H, Morita A, et al. (2015). Predicting early post-partum depressive symptoms among older 
Mahandaru et al./ Hypnotherapy on Postpartum Pain and Depression

primiparous Japanese mothers. Japan J Nurs Sci, 12(4): 297-308. https://doi.org/10.1111/jjns.12069.

Jasim HH, Sulaiman SABS, Khan AH, Rajah UAS (2017). Factors affecting post caesarean pain intensity among women in the northern peninsular of Malaysia. J Clin Diagnostic Res, 11(9): ICo7-IC11. doi: 10.7860/JCDR/2017/25364.10630.

Kaufman J, DeLorenzo C, Choudhury S, Parsey RV (2016). The 5-HT1A receptor in major depressive disorder. Eur Neuropsychopharmacol, 26(3): 397410. doi: 10.1016/j.euroneuro.2015.12.039.

Kendrick C, Sliwinski J, Yu Y, Johnson A, Fisher W, Kekecs Z, Elkins G (2016). Hypnosis for acute procedural pain: A critical review. Int J Clin Exp Hypn, 64(1): 75-115. https://doi.org/10.108o/00207144.2015.1099405.

Kravits K (2013). Hypnosis: adjunct therapy for cancer pain management. J Adv Pract Oncol. 4(2): 83-88. https://dx.doi.org/10.6004\%2Fjadpro.2013.4.2.2.

Madden K, Middleton P, Cyna AM, Matthewson M, Jones L (2016). Hypnosis for pain management during labour and childbirth. Cochrane Database Syst Rev. 2016(5): CDoo9356. doi: 10.1002/14651858.CDoo9356.pub3.

Mubarokah RI, Prasetya H, Respati SH (2020). The Effectiveness of hypnotherapy to reduce anxiety in precaesarean sectio women. J Maternal Child Health, 5(1): 13-17. https://doi.org/10.26911/thejmch.2020.05.01.02

Mughal S, Azhar Y, Siddiqui W (2020). Post-partum depression. StatPearls Publishing. https://www.ncbi.nlm.nih.gov/books/NBK519070/.

Niraski V (2015). Pengaruh hipnoterapi terhadap tingkat nyeri pada ibu post sectio caesarea di RSB Jeumpa Pontianak Tahun 2015. Jurnal Proners. 3(1). http://dx.doi.org/10.26418/jpn.v3i1.11037.

Payne JL, Maguire J (2019). Pathophysiological mechanisms implicated in post-partum depression. Front Neuroendocrinol, 52: 165-180. https://doi.org/10.1016/j.yfrne.-2018.12.001.

Price SA, Wilson LM (2012). Patofisiologi Konsep Klinis Proses-Proses Penyakit. Edisi 6. Jakarta: EGC.

Sado M, Ota E, Stickley A, Mori R (2012). Hypnosis during pregnancy, childbirth, and the postnatal period for preventing postnatal depression. Cochrane Database Syst Rev, (6). doi: 10.1002/14651858.cdoo9062.pub2.

Sadock BJ, Sadock VA (2015) Synopsis of Psychiatry: Behavioral Sciences and Clinical Psychiatry, 11th ed. 11 ed.

Sandall J, Tribe RM, Avery L, Mola G, Visser GH, Homer CS, Gibbons D, et al. (2018). Short-term and long-term effects of caesarean section on the health of women and children. Lancet, 392(10155): 1349-1357. https://doi.org/10.1016/so140-6736(18)31930-5.

Sanders VM (2012). The beta2-adrenergic receptor on $\mathrm{T}$ and $\mathrm{B}$ lymphocytes: Do we understand it yet?. Brain Behav Immun. 26(2): 195-200. doi: 10.1016/j.bbi.2011.08.001.

Setyadi AW, Murti B, Demartoto A (2016). The effect of hypnotherapy on depression, anxiety, and stress, in people living with HIV/AIDS, in "Friendship Plus" peer supporting group, in Kediri, East Java. J Health Promot Behav. 1(2): 99-108. doi: 10.26911/thejhpb.2016.01.02.05.

Thompson T, Terhune DB, Oram C, Sharangparni J, Rouf $\mathrm{R}$, Solmi $\mathrm{M}$, Veronese N, Stubbs B (2019). The effectiveness of hypnosis for pain relief: A 
Mahandaru et al./ Hypnotherapy on Postpartum Pain and Depression

systematic review and meta-analysis of 85 controlled experimental trials. Neurosci Biobehav Rev. 99: 298-310. https://doi.org/10.1016/j.neubiorev.2019.02.013.

Tripathi L, Kumar P (2014). Challenges in pain assessment: Pain intensity scales. Indian J Pain, 28(2): 61. doi: 10.4103/0970-5333.132841.

Varga K, Kekecs Z (2014). L'oxytocine et le cortisol en interaction hypnotique. International Journal of Clinical and Experimental Hypnosis, 62(1): 111128. doi: 10.1080/00207144.2013.841494.

Wahyuni R, Rohani S (2019). Faktor - faktor yang berhubungan dengan riwayat persalinan sectio caesarea, eellness and healthy magazine, 2: 187-192. https://wellness.journalpress.id/wellness/article/view/vii218wh.

Xu H, Ding Y, Ma Y, Xin X, Zhang D (2017). Cesarean section and risk of postpartum depression: A meta-analysis. J Psychosom Res, 97: 118-126. doi: 10.1016/j.jpsychores.2017.04.016.

Yexley MJ (2007). Treating post-partum depression with hypnosis: Addressing specific symptoms presented by the client. Am J Clin Hypn, 49(3): 219223. doi: 10.1080/00029157.2007.10401584 . 